\title{
Functional and morphological differentiation of fetal porcine islet-like cell clusters after transplantation into nude mice
}

\author{
O. Korsgren, L. Jansson, D. Eizirik and A. Andersson \\ Department of Medical Cell Biology, Uppsala University, Uppsala, Sweden
}

\begin{abstract}
Summary. By using a previously described culture technique for the midgestational fetal porcine pancreas, islet-like cell clusters with a Beta-cell frequency of approximately $5 \%$ have been produced in large numbers. These islet-like cell clusters were transplanted beneath the kidney capsule to either normoglycaemic or alloxan-treated nude mice. The grafts consistently failed to cure the alloxan-treated mice immediately after implantation, however, normoglycaemia was restored in a majority of the mice within 2 months after transplantation and in all animals after 4 and 6 months. Indeed, the insulin released from the transplanted fetal Beta cells was able to normalize the serum glucose concentration at porcine levels (4-5 mmol/1) rather than at the level maintained in mice $(8-10 \mathrm{mmol} / \mathrm{l})$. In the cured mice there was a normal secretory response to glucose in the grafts as evidenced by normal glucose profiles during intravenous glucose tolerance test and a biphasic insulin response to high glucose when perfusing the graft bearing kidney. On the other hand, in the normoglycaemic animals the second phase faded before the glucose stimulus had been withdrawn. Two months after transplantation the edocrine cells were arranged so that the endocrine non-Beta cells were randomly scattered
\end{abstract}

among a majority of Beta cells. The cell replication of the Beta cells, measured by ${ }^{3} \mathrm{H}$-thymidine incorporation, was within the lower range of that seen in the native islets of adult mice. No major differences between the controls and the alloxan-treated animals were observed in this respect. Cultured islet-like cell clusters had high rates of glucose utilization, paralleled by low rates of glucose oxidation, compared with adult mouse islets. Following transplantation there was a progressive decrease in glucose utilization and an increase in glucose oxidation. It is concluded that after transplantation the epitheloid cells comprising the porcine islet-like cell clusters can develop into insulin-producing cells with the ability to cure diabetic nude mice. Provided the rejection problems can be overcome the fetal porcine pancreas may be suitable for future clinical xenogeneic transplantations.

Key words: Fetal porcine pancreas, alloxan-diabetes, nude mice, transplantation, insulin secretion, glucose metabolism, labelling index, immunohistochemistry, differentiation.
A major obstacle for the success of clinical islet transplantations has been difficulty in isolating purified islets from the adult human pancreas. Therefore, attention has been paid to the use of alternative sources of pancreatic islets. One possibility would be the use of human fetal pancreases, but a scarcity of suitable donor tissue is a major problem. By using the porcine fetal pancreas, an experimental model for the human fetal pancreas has been obtained $[1,2]$, which may also serve as a possible source for future clinical xenogeneic transplantations, provided the rejection problems can be overcome.

A general finding in fetal pancreatic Beta cells is a lack of glucose-induced insulin secretion [3-5]. Insulin secretion from fetal Beta cells can, however, be stimulated by increased intracellular cAMP levels, caused for example by the combined addition of theophylline and glucose [6]. We have previously described a culture technique, very similar to that used for the human fetal pancreas [7], with which a high number of islet-like cell clusters (ICC) can be obtained from porcine fetal pancreases [1]. The ICC were characterized with regard to their hormonal release, a constant finding being a lack of glucose-stimulated insulin release [1].

The aim of the present investigation was to study first, whether the fetal porcine ICC formed in culture could cure diabetes in nude mice, and second if a glucose-induced insulin release matured with time after transplantation. Morphologic evaluations of the grafted ICC were performed, in order to correlate the cellular composition of the grafts with their functional properties. 


\section{Materials and methods}

\section{Animals}

Pregnant sows, bred by a local farmer, were killed by means of a slaughtering mask at approximately day 75 of pregnancy (range 6878 , term is 115 days). The fetuses were collected from the uterus, placed on ice, and transported to the laboratory (cold ischaemia time approximately $1 \mathrm{~h}$ ). Male, inbred nu/nu C57BL/6J mice (Bomholdtgaard, Ry, Denmark) were used as recipients of the grafted ICC. Some of the animals were made diabetic by an intravenous injection of alloxan $(90 \mathrm{mg} / \mathrm{kg}$ body weight, Sigma, St. Louis, Mo., USA) 4 days before transplantation. The animals were considered diabetic if glucosuric at the time of transplantation, as determined by glucose reagent strips (Clinistix; Bayer, Gothenburg, Sweden). Blood sampling from the retro-orbital venous plexa prior to transplantation was avoided in order to diminish the risk of infection. Normoglycaemic, age-matched, transplanted mice served as controls. All animals had free access to tap water and pelleted food (Type R3; Ewos, Anticimex, Sollentuna, Sweden) throughout the experiments, and were housed one in each cage. The animals were kept in a separate room, at constant temperature $\left(25^{\circ} \mathrm{C}\right)$ and humidity $(60 \%)$. The total mortality of nude mice in the study was approximately $10 \%$, and was mainly confined to the first days after transplantation. A total of 70 nude mice were finally included in the study, of these were 44 alloxan-treated. Eleven alloxan-treated mice were not diabetic at the day of transplantation (see above). In addition, four mice were excluded from the study, because intact islets were found in the native pancreas, or the mice did not turn diabetic after removal of the graft-bearing kidney. Care was taken to secure that ICC from more than one litter of piglets were included in all experimental groups.

\section{Culture and transplantation of ICC}

The culture technique for the fetal porcine pancreas has been described in detail [1]. The fetal pancreases were aseptically removed and minced into fragments with a size of $1-2 \mathrm{~mm}^{3}$. After collagenase digestion ( $\approx 10 \mathrm{mg} / \mathrm{ml}$; Boehringer Mannheim, Mannheim, FRG) during simultaneous vigorous shaking at $37^{\circ} \mathrm{C}$ for 8-10 min, the digest was washed and distributed into tissue culture dishes (Nunclon $90 \mathrm{~mm}$; Nunc, Denmark) containing $9 \mathrm{ml}$ of medium RPMI 1640 (Flow Laboratories, Irvine, UK), supplemented with $1 \mathrm{ml}$ heat-inactivated human serum. The culture dishes were kept at $37^{\circ} \mathrm{C}$ in a gas phase consisting of $5 \% \mathrm{CO}_{2}$ in humidified air, and the culture medium was changed every second day.

The ICC formed after 4 days in culture were either utilized for metabolical studies or transplanted, by means of a braking pipette, under the left renal capsule of avertin-anaesthetized mice. The avertin-solution consisted of $10 \mathrm{~g}$ of 2.2 .2 tribromoethanol $97 \%$ (Sigma Chemicals) dissolved in $10 \mathrm{ml}$ of 2-methylbutan-2-ol (tert. amylalcohol) (BDH Chemicals Ltd., Poole, UK). This stock solution was further diluted with $0.9 \% \mathrm{NaCl}$ to reach a final concentration of $2.5 \%$ which was then given i.p. at a dose of $20 \mu \mathrm{l} / \mathrm{g}$ body weight. ICC produced from the same litter were transplanted into both control and alloxan-treated animals. All animals were given two simultaneous implants of ICC, each with a volume of $3 \mu \mathrm{l}$ of ICC $(2 \times 3 \mu$ l equals a total number of $\approx 500-700$ ICC $)$. The two implants were put side-by-side with a few $\mathrm{mm}$ distance under the left kidney capsule.

\section{Perfusion of the graft-bearing kidneys}

These experiments were performed on kidneys from both control animals and alloxan-treated mice 2,4 or 6 months after transplantation. The technique has recently been described in detail $[1,8]$.
Briefly, the graft-bearing kidney was removed, under Inactin anaesthesia (130 mg/kg body weight i.p.; Byk, Gulden, Konstanz, FRG), together with the abdominal aorta and vena cava. The aorta was cannulated with a polythene catheter which was used to infuse the perfusion medium. This was a Krebs-Ringer bicarbonate buffer $+10 \mathrm{mmol} / 1$ Hepes (KRBH), supplemented with $2.0 \%(\mathrm{w} / \mathrm{v})$ of bovine serum albumin (Fraction V; Miles Laboratories, Slough, UK) and Dextran T 70 (Pharmacia Fine Chemicals, Uppsala, Sweden). The medium was continuously gassed $\left(\mathrm{O}_{2}: \mathrm{CO}_{2}=95: 5\right)$ and administered at a flow rate of $1.0 \mathrm{ml} / \mathrm{min}$ (perfusion pressure $\approx 40 \mathrm{mmHg}$ ) without recycling for $125 \mathrm{~min}$. Both the renal vein and ureter were cut to allow free flow of the perfusion medium. The experiments started with $30 \mathrm{~min}$ of perfusion with medium containing $2.8 \mathrm{mmol} / \mathrm{l}$ glucose followed by $45 \mathrm{~min}$ with $16.7 \mathrm{mmol} / \mathrm{l}$ glucose, $15 \mathrm{~min}$ with $2.8 \mathrm{mmol} / \mathrm{l}$ glucose, $20 \mathrm{~min}$ with $16.7 \mathrm{mmol} / \mathrm{l}$ glucose $+10 \mathrm{mmol} / \mathrm{l}$ theophylline and, finally, $15 \mathrm{~min}$ with $2.8 \mathrm{mmol} / \mathrm{glucose}$. A $1.0 \mathrm{ml}$ sample of the effluent medium was collected every fifth minute, except for the first $10 \mathrm{~min}$ of perfusion with the high glucose concentration when samples were taken after 1-5, 7 and $10 \mathrm{~min}$. The insulin contents of these samples were measured by radioimmunoassay [9]. Stimulation of insulin release was defined as a five-fold increase in hormone secretion over a period of at least 15 min compared with the basal secretion at $2.8 \mathrm{mmol} / 1$ glucose. In the animals examined 6 months after transplantation the total insulin release during glucose stimulation was measured by planimetry of each individual perfusion curve. The first phase of insulin release was defined as the first 10 min of perfusion with $16.7 \mathrm{mmol} / 1$ glucose, whilst the second phase comprised of the following $35 \mathrm{~min}$.

\section{Serum glucose concentrations after transplantation}

All blood samples were collected by puncture of the retro-orbital venous plexa of fed animals before 10.00 hours. The glucose concentrations of the samples were determined with an automated glucose oxidase method (Glucose Analyzer II, Beckman Instruments, Fullerton, Calif, USA).

In a separate group of alloxan-treated and ICC grafted nude mice an intravenous glucose tolerance test (IVGTT) was performed 4 or 6 months after implantation by administering glucose as an i.v. bolus dose of $75 \mathrm{mg}$. Blood samples were collected immediately before and 10,30,60 and $120 \mathrm{~min}$ after glucose administration. No samples were taken after 30 and $120 \mathrm{~min}$ in mice tested 4 months after transplantation. After the IVGTT, the graft-bearing kidney was removed under avertin-anaesthesia (see above). Determinations of serum glucose in these nephrectomized mice were performed 4 days after surgery. The graft-bearing kidney was either dissected free and processed for light microscopy or used for metabolic incubations (6 months, see below).

\section{Morphological examinations}

One hour before removal of the graft-bearing kidney the animals were given an i.p. injection of ${ }^{3} \mathrm{H}$-thymidine $(1 \mu \mathrm{Ci} / \mathrm{kg}$ body weight; Amersham International, Amersham, UK). After the perfusion, the kidney was dissected free from blood vessels and fat, and the graft was excised with a margin of $\approx 3 \mathrm{~mm}$. The graft-bearing kidney and the native pancreas were fixed in Bouin's solution and embedded in paraffin. Also pieces of native fetal pig pancreases, and ICC harvested after 4 days of culture were fixed and embedded according to this procedure. Sections, $7 \mu \mathrm{m}$ thick, were then processed for immunohistochemistry as previously described [1]. The sections were stained in order to visualize amylase (Sigma Chemicals), or, in the same section, insulin and a combination of glucagon, somatostatin and pancreatic polypeptide. This could be achieved by using primary antibodies raised in different species of animals, thereby making it possible to employ two parallel but non-interact- 
ing antibody chains. The first chain consisted of a primary monoclonal mouse antibody raised in mice against human insulin (Amersham). A goat anti-mouse antibody (Zymed Laboratories, San Francisco, Calif., USA) was used as the second layer and finally, an APAAP (alkaline phosphatase) mouse complex (Dakopatts, Glostrup, Denmark) was added. The other antibody chain consisted of a mixture of primary rabbit antibodies raised against glucagon (Milab, Malmö, Sweden), somatostatin or pancreatic polypeptide (both Dakopatts). The second layer was a swine antirabbit antibody and, finally, the PAP (peroxidase) rabbit complex was added (both Dakopatts). To visualize glucagon, somatostatin and pancreatic polypeptide containing cells diaminobenzidine (Polysciences Limited, Northampton, UK) was added for $5 \mathrm{~min}$ and then removed by rinsing in a Tris- $\mathrm{HCl}$ buffer. Then the insulin positive cells were visualized by addition of a mixture of a Fast-Red salt and naphtol AX (both Sigma Chemicals). The incubation was interrupted after $10 \mathrm{~min}$ by rinsing in distilled water. The specificity of the immunostaining was tested according to the recommendations by Goldman [10] and included omission of every single step in the two different antibody- chains. No cross-reactivity was detected at any level.

After the immunocytochemical staining, the slides with sections from the grafted ICC or the native pancreases of the nude mice were further processed for autoradiography as previously described in detail [1], and finally mounted in a glycerol mounting media (Dakopatts). The exposure time was 4 weeks, and a cell was considered labelled with ${ }^{3} \mathrm{H}$-thymidine if more than 20 grains were detected over its nucleus. In each graft more than 4000 endocrine cells were evaluated with regard to immunocytochemical staining and autoradiographic labelling in order to determine the frequency of the different islet cells within the transplants and the labelling index of the insulin positive cells. In the native pancreases 2500 endocrine cell nuclei were counted to assess the corresponding parameters. Due to the scarcity of endocrine cells producing glucagon, somatostatin or pancreatic polypeptide only the frequency and not the labelling index of these cells was determined.

\section{ICC and graft glucose metabolism}

Glucose metabolism was studied by the parallel use of two differently labelled D-glucose molecules [11]. The production of ${ }^{3} \mathrm{H}_{2} \mathrm{O}$ from $\mathrm{D}-\left[5-{ }^{3} \mathrm{H}\right]$ glucose (glucose utilization) is assumed to represent the rate of glycolytic generation of triose phosphates and the conversion of 2-phosphoglycerate into phosphoenolpyruvate. The production of ${ }^{14} \mathrm{CO}_{2}$ from $\mathrm{D}-\left[6-{ }^{14} \mathrm{C}\right]$ glucose represents mitochondrial glucose oxidation. For these experiments non-grafted ICC ( 4 days in tissue culture) or ICC transplanted for 1 or 6 months in alloxan-treated recipients were used. Non-grafted ICC were studied in triplicate groups of 10 . The grafts were removed as previously described [8] and divided into pieces weighing approximately $0.5 \mathrm{mg}$. For measurements of D-[6- $\left.{ }^{14} \mathrm{C}\right]$ glucose $(55 \mathrm{mCi} / \mathrm{mmol}$, Amersham) oxidation, the tissue was transferred to glass vials [12] containing $100 \mu \mathrm{l}$ of $\mathrm{KRBH}$ supplemented with non-radioactive glucose to a final concentration of either 4.2 or $16.7 \mathrm{mmol} / 1$ glucose. The generation of ${ }^{14} \mathrm{CO}_{2}$ was subsequently measured as described in detail elsewhere [13]. The production of ${ }^{3} \mathrm{H}_{2} \mathrm{O}$ from D-[5- $\left.{ }^{3} \mathrm{H}\right]-$ glucose (21.1 Ci/mmol, Amersham) was measured by incubation of the tissue in glass vials containing $100 \mu \mathrm{KRBHsupplemented} \mathrm{with}$ non-radioactive glucose to a final concentration of 4.2 or $16.7 \mathrm{mmol} / 1$ glucose, and the glucose utilization measured as previously described [14]. In the present series of experiments, the recovery of ${ }^{3} \mathrm{H}$ from known amounts of ${ }^{3} \mathrm{H}_{2} \mathrm{O}$ was $58.4 \%$ and the recorded values corrected accordingly.

After the oxidation and utilization experiments the dry weight of the grafts was estimated and the results expressed per $\mu \mathrm{g}$ dry weight. Because it was not feasible to retrieve the ICC after incubation, we determined the weight of three groups of $50 \mathrm{ICC}$ harvested after 4 days in culture. The mean dry weight was $19.5 \pm 3.7 \mu \mathrm{g} / 10 \mathrm{ICC}$. In order to make possible a comparison with the data obtained in the experiments with grafted ICC, all data collected with non-grafted ICC were recalculated using this factor.

\section{Statistical analysis}

Data are expressed as means \pm SEM and have been compared using Student's $t$-test for unpaired observations.

\section{Results}

\section{Serum glucose concentrations}

All alloxan-treated nude mice accepted as recipients were glucosuric and polyuric at the time of transplantation. In a separate study, blood samples were collected from 15 nude mice 4 days after alloxan administration. All these animals had serum glucose concentrations above $22 \mathrm{mmol} / \mathrm{l}$, with a mean of $30.9 \pm 2.3 \mathrm{mmol} / \mathrm{l}$.

The ICC-grafts consistently failed to cure the alloxantreated mice immediately after transplantation as determined by weekly controls of glucosuria. Normoglycaemia was, however, restored in four out of five alloxan-treated animals 2 months after transplantation, and in all animals after 4 and 6 months (Table 1). At these two latter time points the serum glucose concentrations in both control and alloxan-treated mice were approximately 4-5 mmol/1, which is lower than the initial values for the control animals (Table 1).

An IVGTT was performed on some alloxan-treated animals $4(n=9)$ or $6(n=6)$ months after transplantation. At the onset of the IVGTT the basal serum glucose concentrations were significantly lower in the animals having had their ICC grafts for 6 months as compared with those with a 4 months graft $(p<0.05)$ (Fig. 1$)$. Sixty minutes after the glucose administration the serum glucose concentration had returned to the basal values in both groups of mice. The graft-bearing kidney was then removed and the serum glucose concentration 4 days later was $33.1 \pm 1.4$ in the 4 months and $29.8 \pm 1.7 \mathrm{mmol} / \mathrm{l}$ in the 6 months animals.

Table 1. Serum glucose concentrations and body weights at different time points after transplantation

\begin{tabular}{llcl}
\hline Group & $\begin{array}{l}\text { Months after } \\
\text { transplantation }\end{array}$ & $\begin{array}{l}\text { Serum glucose } \\
(\mathrm{mmol} / \mathrm{l})\end{array}$ & $\begin{array}{l}\text { Body weight } \\
(\mathrm{g})\end{array}$ \\
\hline Alloxan-treated & $1(5)$ & $20.6 \pm 3.1$ & $25.9 \pm 0.6$ \\
& $2(5)$ & $13.2 \pm 6.7^{\mathrm{a}}$ & $27.8 \pm 1.4$ \\
& $4(5)$ & $5.0 \pm 0.5^{\mathrm{c}}$ & $29.0 \pm 1.4$ \\
Control & $6(6)$ & $4.3 \pm 0.5^{\mathrm{c}}$ & $29.0 \pm 0.3$ \\
& $1(5)$ & $10.4 \pm 0.9$ & $25.2 \pm 0.6$ \\
& $2(4)$ & $7.3 \pm 0.2^{\mathrm{a}}$ & $30.1 \pm 1.6$ \\
& $4(6)$ & $6.7 \pm 0.3^{\mathrm{b}}$ & $31.0 \pm 1.3$ \\
& $6(7)$ & $4.7 \pm 0.5^{\mathrm{c}}$ & $29.6 \pm 1.3$ \\
\hline
\end{tabular}

Values are means \pm SEM for the number of mice given within parentheses. ${ }^{a} p<0.05,{ }^{b} p<0.01$ and ${ }^{c} p<0.001$ compared with the values obtained 1 month after transplantation 


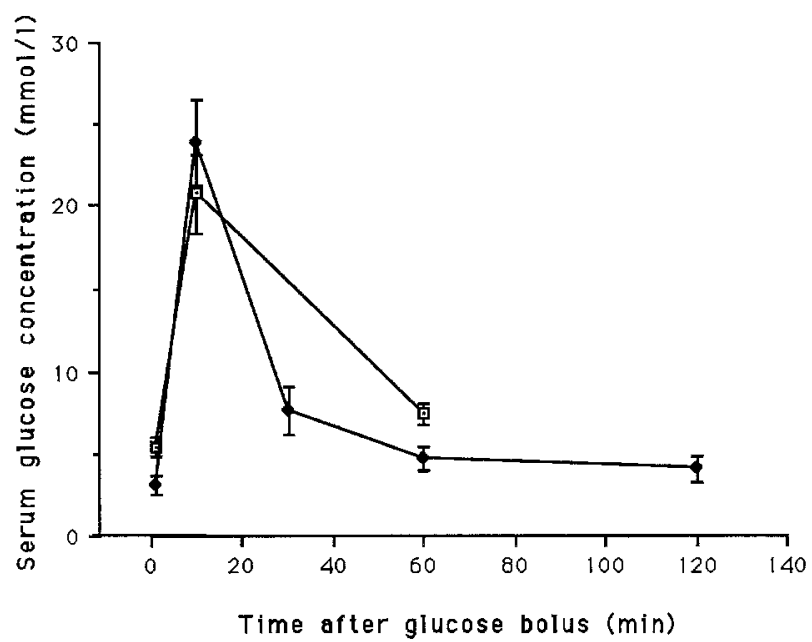

Fig. 1. Serum glucose concentrations at various times after administration of an i.v. bolus dose of glucose $(75 \mathrm{mg})$. The intravenous glucose tolerance test was performed 4 ( $n=9$, open square) or $6(n=6$, filled circles) months after transplantation to alloxan-treated nude mice

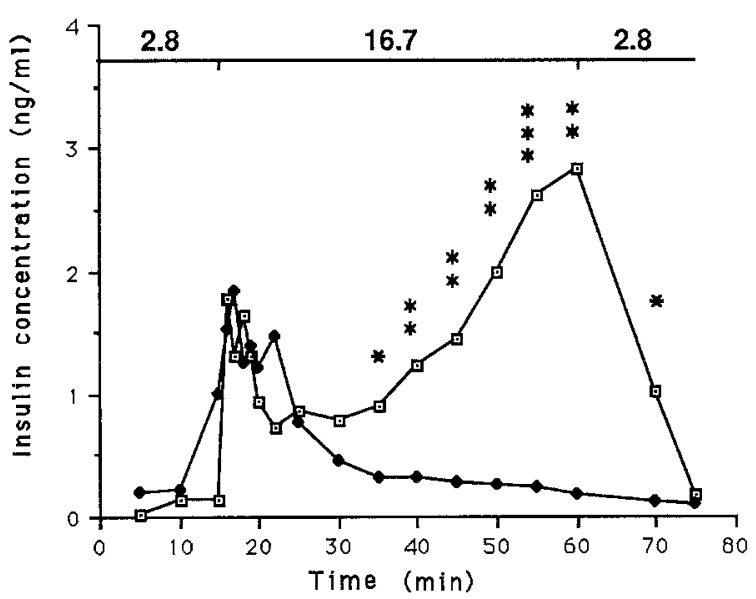

Fig. 2. Insulin concentrations in the effluent medium collected from islet-like cell cluster-grafts perfused 6 months after transplantation. The nude mice were either controls ( $n=6$, filled circles) or alloxantreated ( $n=7$, open squares). Kidneys were perfused with a medium containing either 2.8 or $16.7 \mathrm{mmol} / \mathrm{l}$ glucose as indicated at the top. $* p<0.05, * * p<0.01$ and $* * * * p<0.001$

\section{Perfusion experiments}

Even though four out of the five alloxan-treated mice became normoglycaemic within 2 months after transplantation, a glucose-stimulated insulin release from the grafts was only observed in two of these animals (Table 2). Likewise, all five alloxan-treated mice were normoglycaemic 4 months after transplantation, but only three of them responded when stimulated with $16.7 \mathrm{mmol} / 1$ glucose. Six months after transplantation, however, all grafts removed from the alloxan-treated group possessed a glucose-induced insulin release. A similar development of a glucosestimulated insulin release from the grafted ICC was observed in the control animals. When the perfusion medium was supplemented with $16.7 \mathrm{mmol} / \mathrm{l}$ glucose $+10 \mathrm{mmol} / 1$ theophylline similar results were obtained.
O. Korsgren et al.: Differentiation of porcine islet-like cell clusters

The grafts removed from alloxan-treated mice 6 months after transplantation demonstrated a higher total insulin response during stimulation with glucose than the control animals ( $66.0 \pm 14.9 \mathrm{ng}$ insulin, $n=7$ vs $25.3 \pm 10.2 \mathrm{ng}$ insulin; $n=6 ; p<0.05)$. The individual perfusion profiles of the grafts of the alloxan-treated animals showed a biphasic insulin response to glucose (Fig. 2). On the other hand, in the control animals the second phase faded away before the glucose stimulus had been withdrawn. Indeed, the grafts removed from the alloxantreated animals released $18.1 \pm 2.7 \%$ of their total amount of secreted insulin during the first $10 \mathrm{~min}$ of stimulation with glucose, compared with $46.9 \pm 5.1 \%$ in the control mice $(p<0.01)$.

\section{Morphological studies}

Haematoxylin-eosin stained sections of ICC prepared after culture showed a predominance of epitheloid cells. Immunocytochemical staining for insulin demonstrated only a few positive cells $(\approx 5 \%)$ which were scattered among a majority of unstained cells. These unstained cells were not positive for amylase. A positive reaction for amylase could, however, be found in cells within the native fetal porcine pancreas of the same gestational age (70 days).

A macroscopically evident and marked growth of the transplanted ICC was seen during the first 2 months after transplantation, whereas no further growth was seen after this time point. No differences between the controls and the alloxan-treated animals were observed in this respect. Light microscopical examination of grafts removed 1 month after transplantation revealed a vascularized tissue in which most of the cells were of epitheloid appearance, forming insular nests or duct-like structures (Fig. 3 a). The different endocrine cells within the grafts seemed to be randomly distributed, with glucagon-, somatostatin-, and pancreatic polypeptide-positive cells scattered among insulin-positive cells, the latter constituting approximately $2 / 3$ of the total number of endocrine cells (Fig. 3b, Table 3). Many endocrine cells were found in the duct-like structures. In general, amylase-positive cells

Table 2. Perfusion of the graft bearing kidney

\begin{tabular}{llll}
\hline Group & $\begin{array}{l}\text { Months after } \\
\text { transplantation }\end{array}$ & \multicolumn{2}{l}{$\begin{array}{l}\text { Insulin secretion (responding } \\
\text { animals/total }\end{array}$} \\
\cline { 3 - 4 } & & $\begin{array}{l}16.7 \mathrm{mmol} / 1 \\
\text { glucose }\end{array}$ & $\begin{array}{l}16.7 \mathrm{mmol} / 1 \\
\text { glucose }+\end{array}$ \\
& & $10 \mathrm{mmol} / 1$ \\
& & & theophylline \\
\hline Alloxan-treated 2 & $2 / 5$ & $1 / 5$ \\
& 4 & $3 / 5$ & $4 / 5$ \\
Control & 6 & $6 / 6$ & $6 / 6$ \\
& 2 & $1 / 4$ & $2 / 4$ \\
& 4 & $1 / 5$ & $4 / 5$ \\
& 6 & $6 / 7$ & $7 / 7$ \\
\hline
\end{tabular}

Stimulation of insulin release was defined as a five-fold increase in hormone secretion over a period of at least $15 \mathrm{~min}$ compared with the basal secretion at $2.8 \mathrm{mmol} / \mathrm{lglucose}$ 

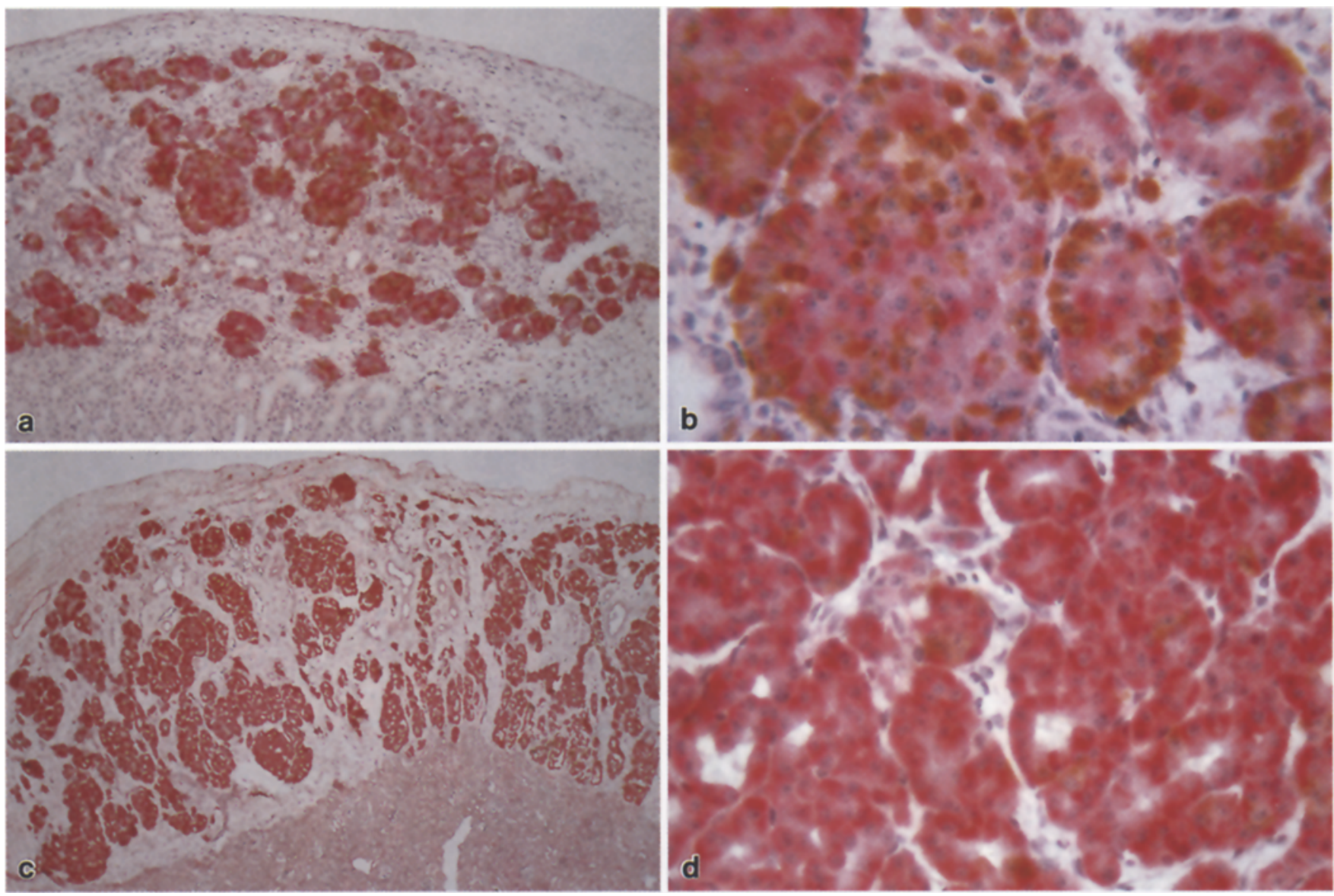

Fig. 3a-d. Light micrographs of fetal porcine islet-like cell clusters after transplantation beneath the kidney capsule of nude mice. The sections were immunocytochemically stained for insulin (red) or glucagon, somatostatin and pancreatic polypeptide (brown) and counterstained with haematoxylin. In the grafts removed 1 month

were few and tended to occur somewhat more frequently in the younger grafts. The epitheloid cells, which did not react with any of the used immunocytochemical stainings, composed approximately half of the total cell number within the grafts 1 month after transplantation. Their number decreased, however, markedly even after 2 months and they were rarely seen 4 or 6 months after transplantation. No attempts were made to determine the exact frequency of these unstained cells. In the 46 months grafts, the cellular architecture changed towards a more cordlike, less isletlike, endocrine tissue constituting approximately $50 \%$ of the total graft volume, separated by strands of connective tissue (Fig. 3c). The frequency of glucagon/somatostatin/pancreatic polypeptide positive cells was markedly lowered compared with that in the grafts removed 1 month after transplantation (Fig. $3 \mathrm{~d}$, Table 3). No marked differences, with regard to Beta-cell frequency and general morphology, were observed between the alloxan-treated animals and the control mice.

In both groups of animals studied a high number of ${ }^{3} \mathrm{H}$ thymidine labelled cells were found in the connective tissue and among the unstained epitheloid cells 1 month after transplantation. Labelled cells were also found in the vascular endothelium of the graft. The frequency of

after transplantation $(\mathbf{a} ; \times 100$ and $\mathbf{b} ; \times 460)$ approximately half of the cells stained positively for the islet hormones, whereas most of the other cells were of epitheloid appearance. Six months after implantation (c; $\times 40$ and $\mathbf{d} ; \times 460$ ), however, the graft contained mainly insulin producing cells, separated by strands of connective tissue

radioactively labelled insulin positive cells was approximately $0.5 \%$ in mice examined $1-2$ months after transplantation (Table 3). The labelling index was markedly reduced 6 months after transplantation.

Light microscopical examination of the pancreases removed from alloxan-treated animals revealed a normal exocrine tissue in which scattered remnants of islets were found. The cells within these islets stained positive for either glucagon, somatostatin or pancreatic polypeptide, whilst only a few insulin positive cells were found. The frequency of insulin positive cells within the native islets of the control animals was $78 \%$ one month after implantation, with a small but significant decrease 6 months after transplantation. The labelling index of the insulin positive cells was very low.

\section{Glucose metabolism experiments}

At both glucose concentrations tested $(4.2$ and $16.7 \mathrm{mmol} / \mathrm{l}$ ) the ICC presented a very active glucose utilization (Fig. 4, top), paralleled by low rates of glucose oxidation (Fig. 4, bottom). Following transplantation to alloxan-treated mice, there was a progressive reversal of 
Table 3. Morphological evaluation of the islet-like cell cluster (ICC) grafts and the native pancreas removed at various times after transplantation

\begin{tabular}{|c|c|c|c|c|c|}
\hline \multirow[t]{2}{*}{ Group } & \multirow{2}{*}{$\begin{array}{l}\text { Months after } \\
\text { transplantation }\end{array}$} & \multicolumn{2}{|l|}{ ICC-grafts } & \multicolumn{2}{|l|}{ Native pancreas } \\
\hline & & $\begin{array}{l}\text { Beta cells (\% of } \\
\text { endocrine cells) }\end{array}$ & $\begin{array}{l}{ }^{3} \mathrm{H} \text {-thymidine labelled } \\
\text { Beta cells (\%) }\end{array}$ & $\begin{array}{l}\text { Beta cells (\% of } \\
\text { islet cells) }\end{array}$ & $\begin{array}{l}{ }^{3} \mathrm{H} \text {-thymidine labelled } \\
\text { Beta cells (\%) }\end{array}$ \\
\hline Alloxan-treated & $\begin{array}{l}1(5) \\
2(5) \\
4(5) \\
6(5)\end{array}$ & $\begin{array}{l}66.4 \pm 1.5 \\
86.0 \pm 1.7^{\mathrm{b}} \\
93.2 \pm 1.0^{\mathrm{b}} \\
93.6 \pm 0.9^{\mathrm{b}}\end{array}$ & $\begin{array}{l}4.4 \pm 0.6 \\
5.0 \pm 0.3 \\
2.5 \pm 0.6^{\mathrm{a}} \\
0.4 \pm 0.2^{\mathrm{b}}\end{array}$ & $\begin{array}{l}- \\
- \\
- \\
-\end{array}$ & $\begin{array}{l}- \\
- \\
- \\
- \\
-\end{array}$ \\
\hline
\end{tabular}

Values are means \pm SEM for the number of animals given within parentheses. ${ }^{\mathrm{a}} p<0.05$ and ${ }^{\mathrm{b}} p<0.001$ compared with the values obtained 1 month after transplantation

this pattern, with a decrease in glucose utilization and a progressive increase in the glucose oxidation rates. It should be noted that the serum glucose concentrations of the alloxan-treated mice 1 month after transplantation was $30.6 \pm 2.5(n=6)$, compared with $3.7 \pm 0.6 \quad(n=8)$ 6 months after implantation.

\section{Discussion}

This study demonstrates that the epitheloid cells forming the porcine ICC can mature into insulin-producing cells after transplantation with the ability to cure alloxantreated nude mice. The organization of the endocrine cells within the grafts was different from that seen in mature is-
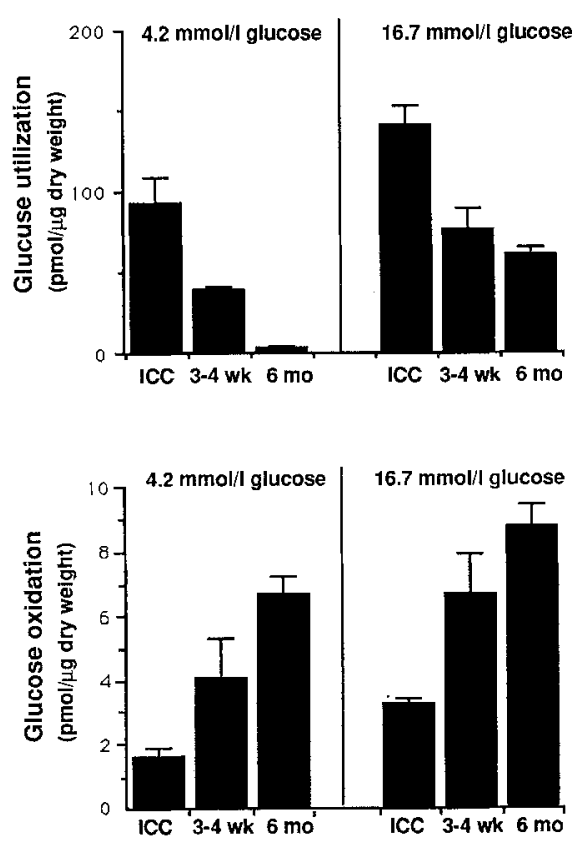

Fig. 4. The glucose metabolism was studied in non-grafted islet-like cell clusters (ICC), or in transplanted ICC 3-4 weeks or 6 months after implantation. The simultaneous use of two differently labelled $D$-glucose molecules enabled measurements of the production of ${ }^{3} \mathrm{H}_{2} \mathrm{O}$ from D-[5- $\left.{ }^{3} \mathrm{H}\right]$ glucose (glucose utilization, top) and ${ }^{14} \mathrm{CO}_{2}$ from D-[6- $\left.{ }^{14} \mathrm{C}\right]$ glucose (glucose oxidation, bottom). Values are means \pm SEM of $5-8$ separate experiments lets of Langerhans, i.e. a central core of Beta cells surrounded by a mantle of glucagon-, somatostatin- and pancreatic polypeptide-producing cells $[15,16]$. The endocrine cells, which composed the major volume of the graft, were arranged so that the endocrine non-Beta cells were randomly scattered among a majority of Beta cells. This morphological maturation of the graft was seen 2 months after transplantation, and correlated in time by the appearance of an insulin secretory capacity as evidenced by lowered serum glucose levels in the recipients.

The high labelling index of the unstained epitheloid cells conforms with the macroscopic growth of the transplanted tissue during the first 2 months after implantation. In parallel with the gradual disappearance of the epitheloid cells there was no further increase in the size of the graft. The proportion of insulin positive cells, however, showed an apparent increase at this point. The labelling index of the differentiated Beta cells was nevertheless within the lower range of that seen in islets of adult mice [17]. This may be taken to indicate that the major source of new Beta cells was from the undifferentiated epitheloid cells of the ICC, rather than from a high replicatory activity in the existing Beta cells.

The present observation of a stimulated insulin release in response to glucose only in the grafts perfused 4 6 months after transplantation is similar to the recent observation by Tuch et al. [5] showing a slow development of the glucose-regulated insulin release in human fetal pancreas grafted to nude mice. Maturation of the embryonal tissues may commence at a very early stage and then proceed at a preset rate which is independent of the environment [18]. Differentiation of the exocrine pancreas depends both on the development of morphogenesis (organization of epithelial cells into exocrine acini) and cytodifferentiation (the appearance of secretory enzymes and zymogen granules). Under experimental conditions, similar to the culture technique used in this study, it was possible to arrest the normal morphogenesis and cell replication of the exocrine pancreas [19], whereas cytodifferentiation proceeded at an unchanged rate. Also in the present study the biological maturation coincided with the chronological age of the tissue, despite the fact that the cellular organization (morphogenesis) within the grafts was quite different from that in the native developing pancreas [15]. 
Hyperglycaemia in vivo may be deleterious to islet function, at least in some strains of animals [20], but whether this is true also for fetal islets is at present unclear. A detrimental effect of a long-lasting diabetes on graft function has been described for fetal pancreas grafts derived from both mice [21] and rats [22]. The grafts in these latter studies were derived from pancreases obtained at late gestation, and then followed for several weeks. In these rodents the endocrine pancreas is known to mature soon after birth [3]. It cannot be excluded though, that the impact of prolonged hyperglycaemia in these studies occurred on endocrine cells with adult rather than fetal characteristics. In the present investigation of the more slowly maturing fetal porcine pancreas, the morphological and functional maturation of the transplanted ICC correlated in time with the reversal of hyperglycaemia in diabetic recipients. No deleterious effects of the preceding hyperglycaemia were observed, on the contrary there was a slight beneficial effect of the diabetic environment. This was most obvious when analysing the perfusion results from grafts removed 6 months after transplantation. Similar beneficial effects of hyperglycaemia on the maturation of human fetal Beta cells have been documented in infants of diabetic mothers [23], or after transplantation of human fetal pancreas to diabetic nude mice $[5,24]$. It should be noted in this context that the normal blood glucose concentration in the present strain of mice is approximately twice that seen in the pig. The Beta cells of the porcine ICC therefore were exposed to either a slight (control mice) or marked (alloxan-treated mice) hyperglycaemia during the first 2 months post transplantation. Thereafter the transplanted porcine tissue seemed to control the serum glucose level. The concept of a low endocrine activity of the native islets, probably due to a relative hypoglycaemia in the recipient, is further supported by the very low labelling index and the progressive decrease in proportion of Beta cells in the pancreases removed from the control mice. This parallels the observation that adult hamster islet-grafts maintain the blood glucose levels in recipient mice at those of normal hamsters [25].

In fetal and other rapidly growing tissues, including fetal rat islets, there is a predominance of the glycolytic pathway over the oxidative glucose degradation [26, 27]. The fetal porcine ICC in this study metabolized glucose in a similar pattern. However, following transplantation there was a progressive decrease in glucose utilization and an increase in glucose oxidation. Although these data must be interpreted with caution, due to the possible contribution of the non-endocrine cells of the grafts, they suggest that, after transplantation, there was a maturation of the glucose metabolism also in the porcine cells. It is conceivable that this mitochondrial maturation causes a progressive enhancement of the glucose-induced insulin release from the grafts.

The observation that porcine Beta cells retain their inherent ability to achieve a glucose homeostasis at the porcine level even after transplantation into another species, would make pigs ideal donors of endocrine pancreatic material for human recipients. Pigs are, like humans, omnivorous and have a relatively similar digestive physiology, glucose homeostasis, and regulation of insulin secretion [28-30]. However, transplanted fetal porcine ICC would constitute a discordant xenograft in humans, i.e. there are naturally occurring preformed antibodies against the transplanted cells present in the recipient [31]. This would make the implant liable to hyperacute rejection. Furthermore, it is known that the amino acid sequence of porcine insulin differs from human insulin in one amino acid [32], and it can be anticipated that such minor species differences exist with regard to a variety of other proteins. It remains to be seen whether such differences will induce antibody formation in the recipient and ultimately ruin graft function.

Acknowledgements. The skilled technical assistance of Ms. B. Bodin, Ms. M. Engkvist, Ms. A. Nordin, and Ms. E. Törnelius is gratefully acknowledged. We are in great debt of gratitude to Ms. K. Johansson for taking care of the nude animals. The study was supported by grants from the Swedish Medical Research Council (12P-8435, 12P-9287, 19P-8982, 12X-109, 12X-8273, 12X-9237-connected to the "Beta-cell Transplant, European Concerted Action for the Treatment of Diabetes"), the Swedish Diabetes Association, the Juvenile Diabetes Foundation International, the Nordic Insulin Fund, the Hoechst Diabetes Foundation, the Ernfors Family Fund, the Ake Wiberg Foundation, the O.E. and Edla Johanssons Foundation, the Torsten and Ragnar Söderberg Foundation and the Swedish Society for Medicine.

\section{References}

1. Korsgren O, SandlerS, Schnell-LandströmA, Jansson L, Andersson A (1988) Large-scale production of fetal porcine pancreatic islet like cell clusters. Transplantation 45: 509-514

2. Thompson SC, MandelTE (1990) Fetal pig pancreas. Preparation and assessment of tissue for transplantation and its in vivo development and function in athymic (nude) mice. Transplantation 49:571-581

3. Asplund K, Westman S, Hellerström C (1969) Glucose stimulation of insulin secretion from the isolated pancreas of foetal and newborn rats. Diabetologia 5: 260-262

4. Rhoten WB (1980) Insulin secretory dynamics during development of rat pancreas. Am J Physiol 239: E57-E63

5. Tuch BE, Jones A, Turtle JR (1985) Maturation of the response of human fetal pancreatic explants to glucose. Diabetologia 28 : 28-31

6. Kervan A, Randon J (1980) Development of insulin release by fetal rat pancreas in vitro: effects of glucose, amino acids and theophylline. Diabetes 29:673-678

7. SandlerS, Andersson A, Schnell A, MellgrenA, TollemarJ, Borg H, Petersson B, Groth CG, Hellerström C (1985) Tissue culture of human fetal pancreas; Development and function of $B$-cells in vitro and transplantation of explants to nude mice. Diabetes 34: 1113-1119

8. Korsgren O, Jansson L, Andersson A (1989) Effects of hyperglycemia on the function of isolated mouse pancreatic islets transplanted under the kidney capsule. Diabetes 38:510-515

9. Heding LG (1972) Determination of total serum insulin (IRI) in insulin-treated diabetic patients. Diabetologia 8:260-266

10. Goldman M (1968) Staining methods, In: Fluorescent antibody methods. Academic, New York London, pp 153-172

11. Sener A, Malaisse WJ (1987) Stimulation by D-glucose of mitochondrial oxidative events in islet cells. Biochem J 246: 89-95

12. Keen H, FieldJB, Pastan JH (1963) A simple method for in vivo metabolic studies using small volumes of tissue and medium. Metabolism 12: 143-147

13. Andersson A, Sandler S (1983) Viability tests of cryopreserved endocrine pancreatic cells. Cryobiology 20: 161-169 
14. Borg LAH, Eide SJ, Andersson A, Hellerström C (1979) Effects in vitro of alloxan on the glucose metabolism of mouse pancreatic B-cells. Biochem J 182: 797-802

15. AlumetsJ, Håkansson R, Sundler F (1983) Ontogeny of endocrine cells in porcine gut and pancreas. An immunocytochemical study. Gastroenterology 85: 1359-1372

16. Orci L, Baetens D, RufenerC, AmherdtM, RavazollaM, Studer P, Malaisse-Lagae F, Unger RH (1976) Hypertrophy and hyperplasia of somatostatin-containing $\mathrm{D}$-cells in diabetes. Proc Natl Acad Sci USA 73: 1338-1342

17. SwenneI, Andersson A (1984) Effect of genetic background on the capacity for islet cell replication in mice. Diabetologia 27 : 464-467

18. Snow MHL, Tam PPL (1980) Timing in embryological development. Nature 286: 107

19. Spooner BS, Cohen H, Faubion J (1977) Development of the embryonic mammalian pancreas: the relationship between morphogenesis and cytodifferentiation. Dev Biol 61:119-130

20. Weir GC, Leahy JL, Bonner-Weir S (1986) Experimental reduction of B-cell mass: implications for the pathogenesis of diabetes. Diabetes Metab Rev 2: 125-161

21. Cuthbertson RA, Koulmanda M, MandelTE (1988) Detrimental effect of chronic diabetes on growth and function of fetal islet isografts in mice. Transplantation 46: 650-654

22. Brown J, Heininger D, Kuret J, Mullen Y (1981) Islet cell grow after transplantation of fetal pancreas and control diabetes. Diabetes 30:9-13

23. Heding LG, Persson B, Stangenberg M (1980) B-cell function in newborn infants of diabetic mothers. Diabetologia 19: 427-432

24. Tuch BE, Grigoriou S, Turtle JR (1989) Effect of normoglycemia on the functional maturation of the human fetal beta cell. Pancreas 4: 587-593

25. LacyPE (1988) Perspectives of islet cell transplantation in diabetes. In: Lefebvre PJ, Pipeleers DG (eds) The pathology of the endocrine pancreas in diabetes. Springer, Berlin Heidelberg New York, pp 310-328

26. Newsholme EA, Crabtree B, ArdawiMSU (1985) The role of high ratios of glycolysis and glutamine utilization in rapidly dividing cells. Biosci Rep 5:393-400

27. Rorsman P, Arkhammar P, Bokvist K, Hellerström C, Nilsson T, Welsh M, Welsh N, Berggren P-O (1989) Failure of glucose to elicit a normal secretory response in fetal pancreatic beta cells results from glucose insensitivity of the ATP-regulated $\mathrm{K}^{+}$channels. Proc Natl Acad Sci USA 86: 4505-4509

28. Kirkman RL (1989) Of swine and men: organ physiology in different species. In: HardyMA (ed), Xenograft 25. Elsevier Amsterdam, pp 125-132

29. Jensen SL, Kuhl C, Nielsen OV, Holst JJ (1976) Isolation and perfusion of the porcine pancreas. Scand J Gastroenterology 37 [Suppl.]: 57-61

30. Crowther NJ, Gotfredsen CF, Moody AJ, Green IC (1989) Immunological and insulin secretory studies on isolated porcine islets of Langerhans. J Endocrinol 126: 43-49

31. CalneRY (1970) Organ transplantation between widely disparate species. Transplant Proc II: $550-556$

32. Chance RE (1972) Amino acid sequences of proinsulins and intermediates. Diabetes 21: 461-467

Received: 2 November 1990

and in revised form: 11 January 1991

Dr. O. Korsgren

Department of Medical Cell Biology

Biomedical Centre

Box 571

S-751 23 Uppsala

Sweden 